\title{
自己フィードバックによるプレゼンテーション能力の 向上を目指した取り組み
}

A Study on Improvement in Presentation Skills of Students with Self-feedback

\author{
河 合 宏 之 $^{2}$ \\ 松 石 正 克*2 \\ Hiroyuki KAWAI \\ Masakatsu MATSUISHI
}

\begin{abstract}
This paper discusses how to improve oral presentation skills of students of engineering design courses based upon the PDCA cycle. In this paper the authors proposed a method to improve the presentation skills as follows. We gave assignments to evaluate their presentation skill by observing videos of their presentation. We encouraged our students to feedback the evaluation into the following presentation. By repeating the evaluation and feedback cycle, students achieved considerable progress in oral presentation.
\end{abstract}

Keywords : Engineering Education, Presentation Skills, Self-feedback, Educational Effect キーワード : 工学教育, プレゼンテーション能力, 自己フィードバック, 教育効果

\section{1.はじめに}

近年, 教育改善を目的としてPlan-Do-CheckAct（PDCA）サイクルを適用した教育プログラムが 提案されている ${ }^{1)}$. 金沢工業大学に招いてはPDCAサ イクルをベースとして教員が授業を見直し改善して いることはもちろん ${ }^{2)}$, 平成18年度現代的教育ニーズ 取組支援プログラム（現代GP）における地域連携プ ロジェクト ${ }^{3)}$ でもPDCAサイクルが適用されている. 教育を受ける学生の視点で考えた場合，たとえば座学 の科目に扔けるサイクルでは

Plan：シラバスなどの学習計画書

Do：授業（予習や復習を含む）

Check：小テスト，レポート，定期試験など

Act：理解できていない箇所の自学自習

と表現できる(図 1参照).

このPDCAサイクルは, 元々は生産過程における品

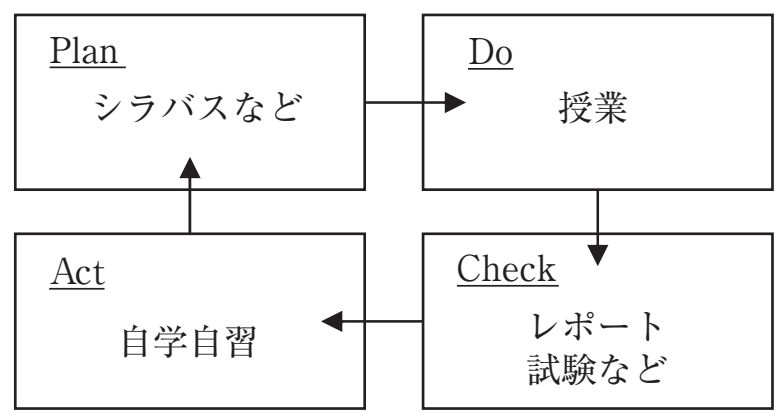

図 1 学生視点での座学科目に対する PDCA サイクル

平成 19 年 6 月 7 日受付

※ 1 金沢工業大学工学部

※ 2 金沢工業大学基礎教育学部
質の維持・向上を断続的におこなうプロセスを表現し たものであり，PDCAの 4つのステップが必要である ことはいうまでもないが, 本質的にはそのサイクルを 回す（フィードバックする）ことが重要となる ${ }^{4}$.

金沢工業大学ではこのような教育改善を行いなが ら，学生を自ら行動する技術者へと成長させることを 目指している ${ }^{5)}$. そのため「1. 新しい問題を見出す 能力」, 「2. 問題を解決できる能力」, 「3. チーム の一員として活動し，リーダーシップを発揮できる能 力」,「4.コミュニケーション能力」を育成するため の教育を害施している. 一方, 実社会においても上述 した能力が必要とされており, 特に近年では, 若者の コミュニケーション能力不足が問題となり, その対策 としてのコミュニケーション教育を実施している企業 もあり ${ }^{6)}$, 在学時のコミュニケーション能力の向上が ますます求められている.

そこで本稿では，大学で育成すべき能力のひとつで あるコミュニケーション能力, なかでもプレゼンテー ション能力の向上にフィードバック構造を導入する取 り組みについて報告する。特に本稿での取り組みは, 大学内のITインフラストラクチャー (以下, 学内イ ンフラ）を利用し，比較的大人数が受講する科目でも 実現可能で, かつ学生自身がPDCAサイクルを回す (自 己フィードバックする) ことが可能な自学自習型の取 り組みとなっている.

\section{2. 工学設計科目における取り組み}

2. 1 工学設計科目の概要

金沢工業大学では先に述べた 4 つの能力を育成する 
ための工学設計教育を実施している. 中心的な科目と して全学生にとって必修科目となる工学設計 I ・ II お よびIIIが， 1 年次， 2 年次， 4 年次に開講されている. 工学設計 III が所属学科の専門教育のまとめとして能力 の総合化を目指す科目であり従来型の卒業研究に相当 するのに対し, 工学設計 I ・ II では基礎教育のまとめ として実施される科目と位置づけられる。

工学設計 I および II は，1 学年約1,700名を対象（各 50クラス開講）とした，比較的大人数が履修する科目 である. 本科目における設計活動は, 「1. 問題の発見」, $\lceil 2$. 問題の明確化」,「3. 解決案 (策) の創出」, 「4. 解決策の評価・選定」「「5. 解決策の具体化」の 5 つ の設計過程から成り立っている. 工学設計 I では前半 の設計過程に, 工学設計 II では主に後半の設計過程に 取り組む流れとなっており，週 2 コマ (1 コマ60分) の講義が 1 学期間（10週間）開講される.

両科目とも先に挙げた設計活動を通し問題発見・解 決能力を培うのはもちろんのこと, 技術者として成 果を外部に知らせる発信能力を高めることも目標と している，そのため, プレゼンテーションを抏こなう 口頭発表が班ごとに 5 回（進渉状況報告 4 回 + 最終口 頭発表 1 回）あり, 受講生は平均して 2 回の進渉状況 報告の発表を経た後, 必須の最終口頭発表に臨むこと になっている.したがって, 最終口頭発表までに受講 生には 2 回の発表練習の機会が与えられることにな

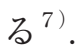

\section{2 プレゼンテーション教育の現状}

一般的にプレゼンテーション能力を高めるには

1 ）理想的な発表を知る (Planに相当)

2）発表をする（Doに相当）

3 ) 現状の自分の能力を把握する (Checkに相当)

4）発表を改善する (Actに相当)

5） 1 - 4 を繰り返す

が必要となる。工学設計 I ・ II では, 理想的な発表を 学生に理解させるために, 発表のガイドラインとして ・聴衆の顔を見ながら話をする

・ポインターを有効に利用する

・適切な言葉を使用する

・原稿を読まない

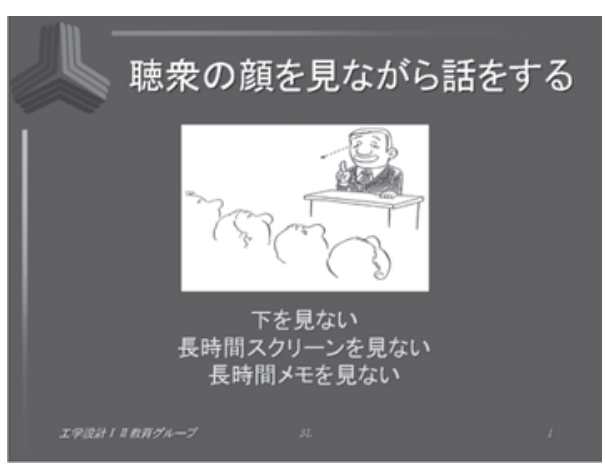

図 2 発表のガイドラインの 1 例

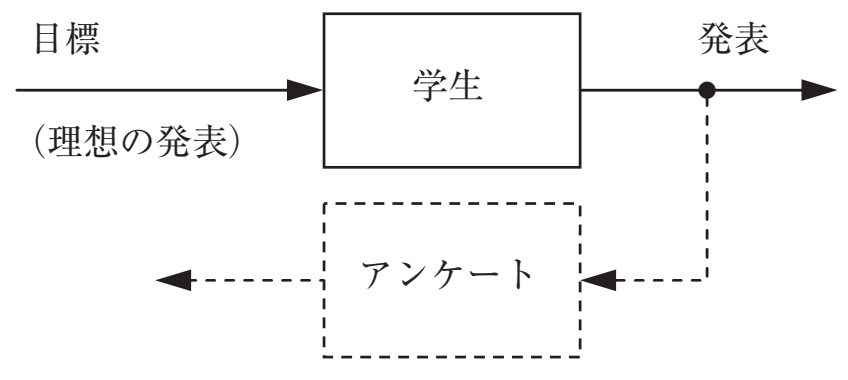

図 3 発表における現状

など，よい発表方法の例（または悪い例）を具体的に 挙げて指導している (図 2 参照)。プレゼンテーショ ン能力向上のために教員が個別指導をおこなうのが理 想的ではあるが，すべての学生に直接発表指導するに は人数的にも時間的にも困難であり, 自分の発表能力 を把握するのは学生自身に任せているのが現状であ る.

そこで従来までは, 口頭発表能力を含む自己能力を 学生自身に把握させるために, 工学設計 I ・II ではす べての受講生に対して第 1 週, 第 5 週, 第 9 週に自己 能力（口頭発表能力, レポート作成能力など）に関す るアンケートをおこなっていた (付録参照). このア ンケートでは, 口頭発表に関していえば「自分の発表 を思い出しながら評価する」といった，いわば間接的 な評価となっている. さらに従来の取り組みでは, 多 くの学生は「こんな発表がしたい」という理想があっ ても, 自分の発表を直接見ていないため現在の自分 の能力を客観的に捉えることができず,「発表を改善 するためにはどうしたらいいのか?」がわかりにくく なっている．言い換えると，PDCAサイクルにおいて はCheckを十分におこなうことができず，学生にとっ ては目標としての理想の発表のみが与えられている状 況（図 3 参照）に近いと考えられる.

そこで，次節では学生自身が自分の能力を客観的に 捉えることができるように，従来までおこなっていた アンケートに加え, 新たにおこなった直接的な自己 フィードバックの取り組みについて述べる.

\section{3 自己フィードバックの取り組み}

現状の工学設計 I ・ II におけるプレゼンテーション 教育では，アンケートをおこなうことで学生自身に自 己能力をかえりみるきっかけを与えているものの, 自 己能力を把握させるための材料を与えていなかった. そこで, 学生に自ら改善点を明確にさせる（理想と現 在の能力の偏差をとるCheckに相当）ための自学自習 型の取り組みとして, 発表の自己評価を課題として 与えた。 具体的には, 学生の発表をビデオカメラで撮 影し, 授業後に自らの発表を評価し報告する課題であ る. 発表の様子を撮影したビデオデータは, 授業終了 後にMPGファイルに変換されクラス毎に用意された Web上の専用ページにアップロードさる (図 4 参照). 自分が発表をしない週では，代わりに他の班員の評価 


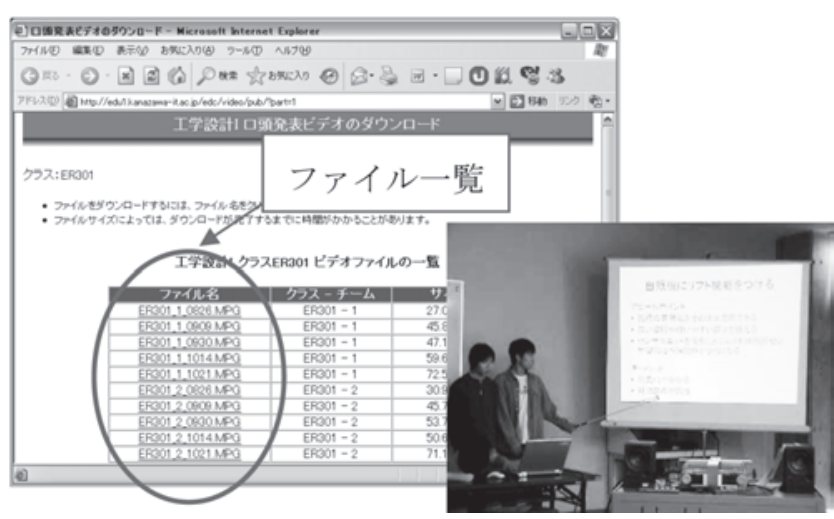

図 4 発表動画のダウンロードページと動画の一部

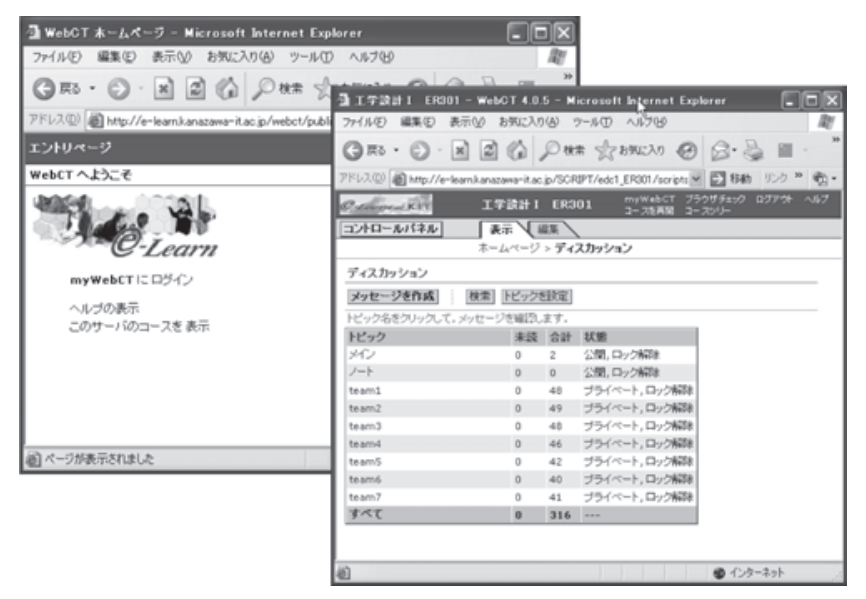

図 5 WebCT（学習支援ソフト）

をおこなう。この評価報告は, 班ごとに用意されて いる専用のWebページ（学習支援ソフトのひとつで WebCTと呼ばれる）の電子掲示板の機能を用いてお こなう (図 5 参照)。したがって，各自が自己評価お よび班員の評価を報告するだけでなく，発表者が班員 からの評価も閲覧することが可能となっている.

本学内にある自習室, レストラン, ラウンジやロ ビーなどには総数約 7,000 個のネットワークコンセン トが設置されており，24時間利用可能である。また， 大学周辺の下宿には学内LANが整備されており学内 のネットワーク環境をそのまま利用でき，外部のネッ トワーク環境からはRemote VPNサービスを利用する ことで学内LANにアクセスできるため, 学生は自分 たちの発表を各自のパソコンでいつでも確認すること が可能となっている (図6 参照)。本稿で紹介する取 り組みは, この学内インフラを利用しているため, 工 学設計 I ・ II を受講する比較的大人数の各学年約 1,700 名（50クラス）の受講生に対して適用することが可能 である.

本稿での取り組みであるビデオによる自己評価（課 題）は自己フィードバックの材料を提供するものであ り, 課題の狙いは

1. 発表の理想と現状との偏差を意識的にとる

2. 他人・班員の発表技法を注意深く見る（聞く）

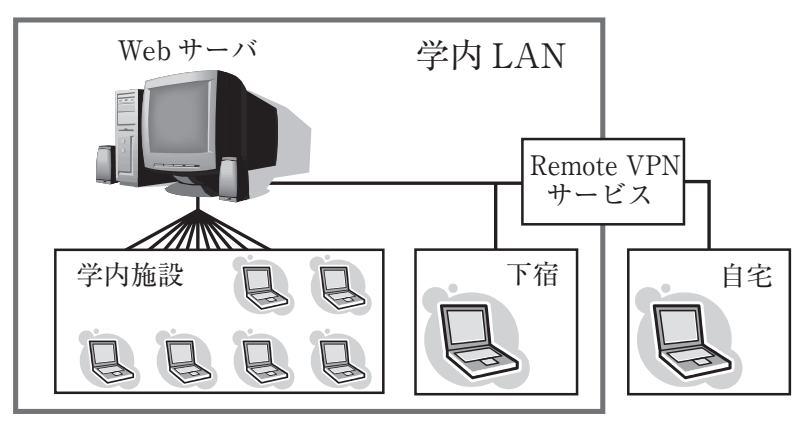

図 6 学内インフラ

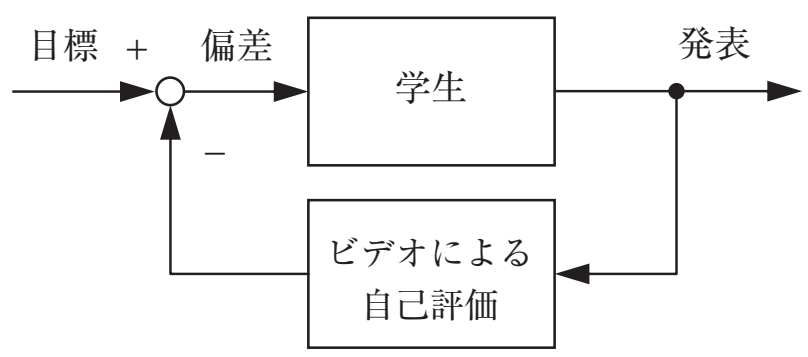

図 7 発表の自己フィードバック

の 2 つが主なものとして挙げられる. 前者は発表の改 善点を明確にし, 後者は良い例・悪い例を含めて目 標をより具体的にするためのものである.この自己 フィードバックの構造を図 7 に示す. 図 3 と比べると 明らかなように, 発表に関する課題を課すことで学生 自身が意識的に偏差をとる（Checkする）ことが可能 となっている.

\section{4 口頭発表能力の初期状態}

受講生の口頭発表能力の初期状態を明確にするため に, 1 年次に受講する工学設計 I の 2 クラスの第 1 週 目のアンケート結果(従来の取り組みで得られる結果) を図 8 に示す. 尚, 図 8 は様々な自己能力に関するア ンケートの中で, 口頭発表に関する設問だけを抜粋し, 平均值をとることで, 口頭発表の能力を「出来る・ま あ出来る・どちらとも言えない・あまり出来ない・出 来ない」と 5 段階で評価したものである. 図 $8(\mathrm{a}) \cdot(\mathrm{b})$ にそれぞれ自己評価の課題を課していないクラス・課 したクラスの結果を示す. 図 8 より,受講前に「出来る・ まあ出来る」と答えた学生がどちらのクラスも $20 \%$ 程 度である。したがって, 今回対象とした 2 クラスの口 頭発表能力の初期状態は，ほほ同等であると考えられ る.

\section{3. 取り組みの結果および考察}

\section{1 自己評価の内容}

プレゼンテーション能力の向上を狙い, 課題として 与えた自己評価において, 発表を評価する項目として a ．声の大きさ

b. 話す速さ

c. 態度（聴衆の目を見て話す）

d. 技量（ポインターの使い方） 


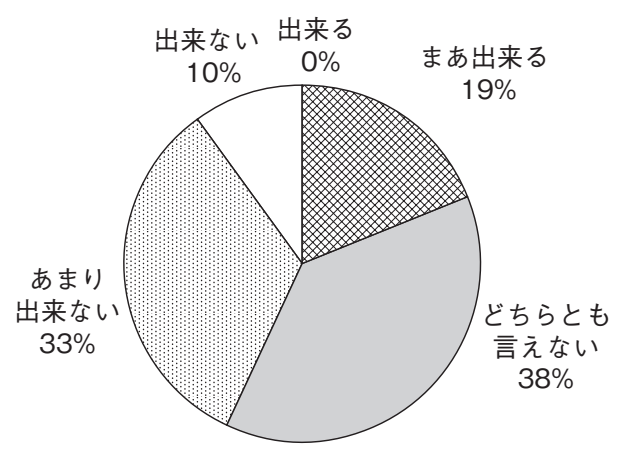

（a）ビデオによる自己評価なし

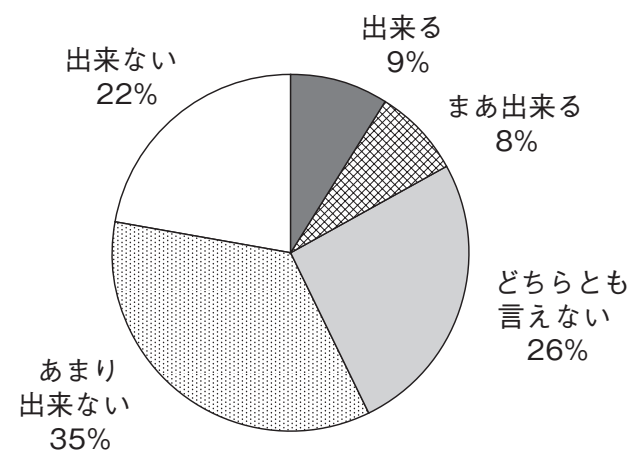

（b）ビデオによる自己評価あり

図 8 工学設計 I の口頭発表に関するアンケート 結果の比較（第 1 週）

e．論理性（話が理解しやすい）

の 5 つを挙げ, 各項目を 4 段階で評価をさせた。 また, 自由記述として

f 。良かった点

$\mathrm{g}$. 改善が望まれる点

を報告させた.この評価内容そのものは次報で検討し， 本稿では自己評価をおこなうことで得られるフィード バック効果について報告する。 そこで，次節では受講 生を対象に㧍こなったアンケート結果を示す。

\section{2 自己評価フィードバックの結果および考察}

先に述べたように，工学設計 I ・ II ではすべての受 講生に対して第 1 週，第 5 週，第 9 週に口頭発表を 含む様々な能力に関するアンケートをおこなってい る。このアンケート結果を利用し，発表の自己評価の フィードバック効果を検討する。

はじめに，第 5 週目が終わった時点でのアンケート 結果を図 9 に示す. 図 9 (a)・(b) は図 8 と同様に, それぞれ工学設計 I で自己評価の課題を課さなかった クラスと課したクラスの結果である。図 9 (a) ・ (b) の両図から, どちらのクラスも全体的に発表能力は向 上しており, 向上の度合いにも違いは見られないと判 断できる。これは，第 5 週目の時点では，各自が 1 回 ずつしか発表しておらず，自己分析や自己評価をし た結果を口頭発表に活かせていない為であると考えら れる。また図 8 （b）と図 9 （b）から，自己評価の 課題を課したクラスにおいて, 出来ると評価した学生 が $9 \%$ から $3 \%$ に減少していることもわかる。これは

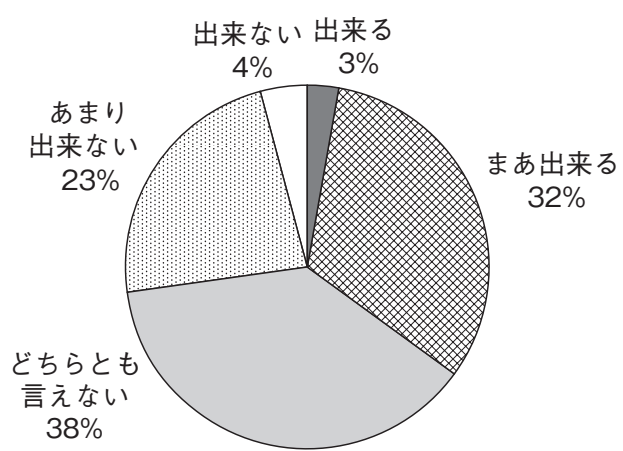

（a）ビデオによる自己評価なし

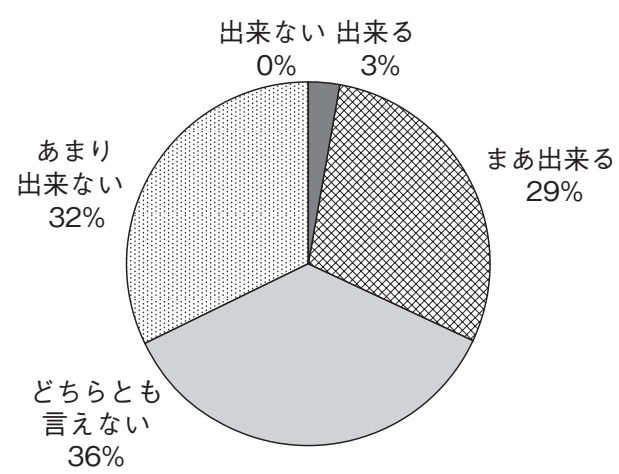

（b）ビデオによる自己評価あり

図 9 工学設計 I の口頭発表に関するアンケート 結果の比較（第 5 週）

講義を受けて良い口頭発表とはどのようなものかを理 解し，また他人の発表を注意深く見ることにより，結 果的として目標が上がった事がひとつの原因であると 解釈できる，逆に，受講前において口頭発表ができる と判断していた学生は, 目標とする口頭発表が具体的 には明確になっていなかった可能性があると推測され る.

つぎに, 第 9 週目 (最終口頭発表) 終了後におこ なったアンケートの結果を図10に示す，図10 (a)・(b) は図 8 や図 9 と同様に，それぞれ工学設計 I において 自己評価の課題を課さなかったクラスと課したクラス の結果である. 図 8 と図10より, 受講後には自己評価 をしていないクラスでは最終的に「出来る・まあ出来 る」と答えた学生が $60 \%$ 程度までの増加であったのに 対し, 自己評価をしたクラスでは $80 \%$ 程度まで増加し ている．今回実施した自己フィードバックの効果が, この増加数の差に表れていると考えられる。 また図 9 と図10より，自己評価の課題を課したクラスでは，第 5 週目から第 9 週目にかけての能力の向上が顕著であ ることからも, 自己評価をつぎの口頭発表に繋げる機 会を持つことが重要であると考えられる.

反対に「出来ない」と答えた学生が両クラスとも $0 \%$ となっていることから，自己評価を意識的におこなわ ない場合でも発表回数を重放ることで発表能力は身に ついていくと思われる．しかしながら，少ない練習の 機会の中で効率よく発表能力を上げるためには, 意識 的な自己評価による自己フィードバックが有効である 


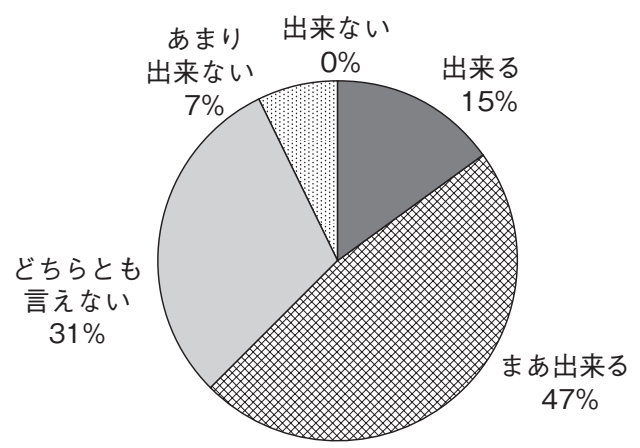

（a）ビデオによる自己評価なし

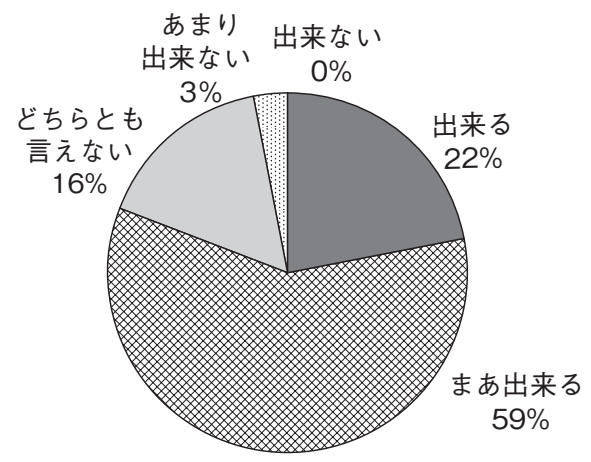

（b）ビデオによる自己評価あり

図 10 工学設計 I の口頭発表に関するアンケート 結果の比較（第 9 週）

\section{と考えられる。}

なお，学生にはこれらのアンケートは成績に関係し ないことを説明しており，教員が最終口頭発表を15点 満点で評価したところ，自己評価なしのクラスでは平 均12.8点, 自己評価ありのクラスでは平均13.9点であっ たことから，学生はアンケート回答の際に発表能力を 過大に評価しておらず，ここで示したアンケート結果 も妥当な結果であると考えられる。

最後に, 2 年次の工学設計 II を受講した学生に同様 に口頭発表のビデオを用いた自己評価の課題を課し， 他人の発表技法への注意度について，発表の良し悪し を意識して聞いたことがあるかどうかのアンケートを とった，ただし，ビデオによる自己評価の課題は本年 度からの取り組みのため, これらの学生は前年度の工 学設計 I ではビデオによる自己評価はおこなっていな かった点に注意しておく、本科目を受講前と受講後に とったアンケート結果を図11に示す。工学設計 II を受 講した学生は前年度に工学設計 I を修得済みにも関わ らず，受講前の回答では65\%程度の学生しか他人の発 表技法を意識して見ていなかったのに対し，受講後に は全学生が意識して見るようになっていることがわか る。これは，今回実施したビデオによる自己評価の課 題が，口頭発表に関する目標を学生自身が改善する仕 組みを有する取り組みになっていると考えられる。

\section{4.おわりに}

本稿では, 学生のプレゼンテーション能力を高める

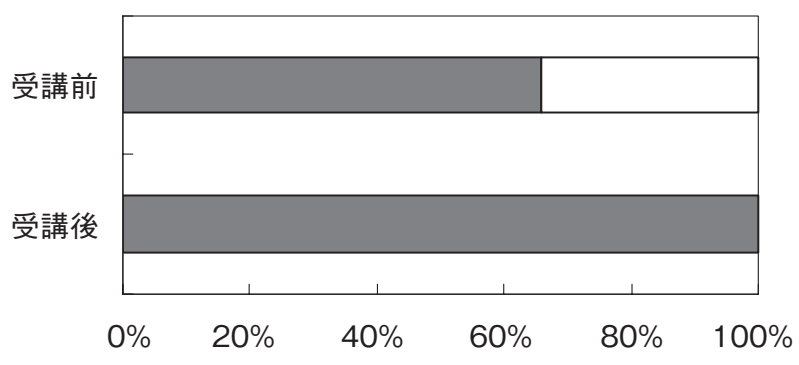

口他人の発表の良し悪しを意識して聞いたことがある 口他人の発表の良し悪しを意識して聞いたことがない

図 11 工学設計 II における発表技法への注意の有無の アンケート結果

ために工学設計科目で実施した自己評価のフィード バック法について報告した. またアンケート結果から， （1）発表能力の偏差をとる，（2）他人の発表技法を注 意梁く見る，という自己フィードバックの 2 つの狙い に対する有効性を検証した。ここで紹介した取り組み は, 既存の学内インフラを有効利用した方法であり, 新たな設備投資をすることなく, 比較的大人数の学生 に対して提供できる点が特徴である.

自己フィードバックによる自学自習方式の教育は, 本稿で対象としたプレゼンテーション能力向上の他に も適用できると考えられる，座学に扔いては，一見す るとPDCAサイクルが回っているように思われるが, Check に相当するレポートや試験を受けた後の自己 評価は学生自身に任されているため, すべての学生が 自己フィードバックをおこなっているとは必ずしもい えない。そこで例えば，試験で間違えた問題のみを 後日レポートとして提出させることで, 自己フィード バックの仕組みを必然的に取り入れることも可能であ る.このように, 自己フィードバックそのものは教育 の仕組みのひとつであり, 実技教育に限らず, 座学の 科目でも適用可能であると考えられる。

\section{参 考 文 献}

1 ）都倉信樹：創成科目の考え方と実施案, 平成 12 年 度工学・工業教育研究講演会 講演論文集, pp. 275 $-278,2000$

2 ) 敷田麻実：サーキットモデルによる創成教育の学 習モデル, 工学教育, $53-1$, pp. 35-40, 2005

3 ) http://www.kanazawa-it.ac.jp/about/hyoka/ gp18g.html

4) W. E. Deming : Out of the Crisis, MIT Press, 2000

5 ）石川憲一：金沢工業大学における教育改革への取 り組み一知識から知恵に一, 金沢工業大学, 2003

6 ) 磯貝, 鈴木：デンソーにおけるテクニカルコミュ ニケーション教育, 工学教育, $54-5, \mathrm{pp} .80-83$, 2006

7 ) 松本, 前川, 久保, 松石 : 金沢工業大学の工学設計 
表 1 口頭発表に関するアンケート項目

\begin{tabular}{|c|c|c|c|c|c|}
\hline & \multicolumn{2}{|c|}{ 工学設計 I } & \multicolumn{2}{|c|}{ 工学設計 II } \\
\hline & & 授業内容 & 達成レベル & 授業内容 & 達成レベル \\
\hline A 1 & $\begin{array}{l}\text { 図, グラフ, 表, イラスト等を効果的に使用し } \\
\text { て発表することができる }\end{array}$ & $\bigcirc \bigcirc$ & $\bigcirc \bigcirc$ & $\bigcirc \bigcirc$ & $\bigcirc \bigcirc \bigcirc$ \\
\hline A 2 & $\begin{array}{l}\text { 発表用原稿を見ないで聞いている人達の眼を見 } \\
\text { ながら発表することができる }\end{array}$ & $\bigcirc \bigcirc$ & $\bigcirc \bigcirc$ & $\bigcirc \bigcirc$ & $\mathrm{OO}$ \\
\hline A 3 & $\begin{array}{l}\text { 聞いている人達からの質問に適切に答えること } \\
\text { ができる }\end{array}$ & $\bigcirc \bigcirc$ & $\bigcirc \bigcirc$ & $\bigcirc \bigcirc$ & $\bigcirc \bigcirc \bigcirc$ \\
\hline A 4 & $\begin{array}{l}\text { 他の人の発表に対して適切な質問をすることが } \\
\text { できる }\end{array}$ & $\bigcirc \bigcirc$ & 00 & 00 & 000 \\
\hline
\end{tabular}

表 2 工学設計 I ・ II における達成レベルの対応

\begin{tabular}{|c|l|l|}
\hline \multicolumn{1}{|c|}{ 記 号 } & \multicolumn{1}{|c|}{ 授業内容 } & \multicolumn{1}{|c|}{ 達成レベル } \\
\hline$\bigcirc \bigcirc \bigcirc$ & 内容の詳細な説明を行う & 完全に実行することができる \\
\hline$\bigcirc \bigcirc$ & 内容の説明を行う & 少しは実行することができる \\
\hline$\bigcirc$ & 目標と関わりがあることには言及する & 試行的に行うことができる \\
\hline (空白 $)$ & 全く触れない & 学習目標とは無関係である \\
\hline
\end{tabular}

I ・ II について, 設計工学, 36-8, pp.349-355, 2001

付

録

工学設計 I ・ II の第 1 週，第 5 週，第 9 週で従来か ら学生がおこなっている能力の自己評価に関するアン ケートの一部を表 1 に示す。まず，アンケートをする にあたり，授業内容の何が重要であるかを理解し，達 成レベルを向上させることが必要であるため, 学生に は学習目標の項目別に, 授業内容と求められる達成レ ベルを提示している，表 1 で○記号を用いて表した授 業内容と達成レベルの意味を表 2 に示す.

実際におこなっているアンケートの質問事項は，実 社会で活躍する能力に関するものとして
A. 口頭による発表（表1のA 1 ～A 4)
B. 文書による表現（レポート）
C. チームの一員として行動する能力
D．技術者として行動をする

の 4 つのカテゴリで12個ある. また, 工学設計過程の 理解に関するものとして
E。必要な情報を収集し, 活用する

F．プロジェクトテーマを見つけ出す

G. プロジェクトテーマを明確にし, 設計仕様を作 成する

H. 解決策を創出する

の 4 つのカテゴリで 9 個の質問事項がある. 学生はそ れぞれの質問事項において表 1 と表 2 で示されるよう な達成レベルに対して，5段階で評価する。

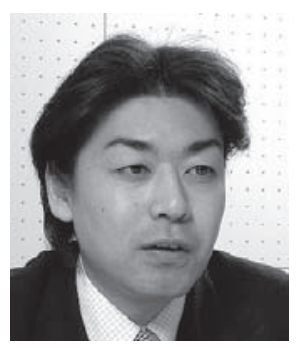

\section{著者紹介}

\section{河合 宏之}

1999年金沢大学工学部電気・情報工学科 卒業. 2001年金沢大学大学院博士前期課 程修了, 2004年金沢大学大学院博士後期 課程修了, 同年法政大学情報技術（IT） 研究センターポストドクター, 2005年金 沢工業大学講師. 視覚フィードバック制 御に関する研究に従事. 博士 (工学). 計 測自動制御学会, システム制御情報学会, IEEEの会員 